\title{
COVID-19 and India's Trail of Tears
}

\section{Chandana Mathur ${ }^{1}$}

Published online: 28 August 2020

(C) Springer Nature B.V. 2020

The COVID-19 pandemic has made plainly visible what has always been true, viz. that in capitalist nation-states, an electorate's voting decisions are a matter of life and death. In the year 2020, the people of India are paying with their lives for the election victory in May 2019 of the Hindu-supremacist Bharatiya Janata Party (BJP) and its strongman Prime Minister Narendra Modi.

The COVID-19 crisis could not have arrived at a more opportune time for the BJP government, rocked as it was by the large-scale protests that had erupted following the passage of the Citizenship Amendment Act (CAA) in December 2019. The Act expedites the granting of Indian citizenship status to non-Muslim religious minorities from Pakistan, Bangladesh and Afghanistan, but withholds this privilege from Muslim applicants. This is the first time that religious profiling, prohibited by the Indian Constitution, will explicitly be used to deny Indian citizenship to Muslim applicants. Home Minister Amit Shah had stated in the Indian Parliament in summer 2019 that the National Register of Citizens (NRC), a brutal bureaucratic exercise conducted in the north-eastern state of Assam that threatens nearly two million people with statelessness, would be extended to cover all of India. Widespread fears that the two initiatives would be used in conjunction with each other-whereby the NRC will declare impoverished Indian Muslims lacking requisite documents as foreigners while the CAA will ensure that they are ineligible to apply for citizenship - led to nationwide protests.

Millions of people across the country, of all ages and religions, ethnic and caste backgrounds, and of varied political persuasions, came out into the streets to protest the anti-Muslim character of the new law. Young people were the first to dominate these demonstrations. The student marchers' calls for protest were echoed across Indian society, by Dalit groups, the gay community, trade unions and the entire political opposition. The scale of these protests was reminiscent of the days of India's decolonisation struggle: a Bharat Bandh, or national shutdown, called by the trade union movement brought out an estimated 250 million protesters across the country on 8 January 2020 (Panicker 2020). If there was an initial concern with brandishing the multi-religious character of the opposition to government-imposed anti-Muslim measures, it soon gave way to an unapologetic resistance that refused to downplay Muslim

Chandana Mathur

Chandana.Mathur@mu.ie

1 Department of Anthropology, Maynooth University - National University of Ireland Maynooth, Maynooth, Ireland 
involvement. In this respect, there is some similarity with the way in which the "Black Lives Matter" movement has come to gain wider acceptance in the USA in the wake of the killing of George Floyd. The enduring symbol of the anti-CAA/NRC/NPR resistance was Shaheen Bagh, a neighbourhood in New Delhi, where a group of Muslim women (many of them very elderly) and their supporters held a continuous sit-down protest that began three days after the passage of the CAA in December 2019 and was ended by the police on 24 March 2020, the day that Modi announced India's COVID-19 lockdown.

Announced with about four hours of notice on March 24, India's lockdown has been regarded as one of the world's most stringent (Petherick et al. 2020). Before and after it went into effect, PM Modi addressed himself solely to those Indians whose class standing ensured lifestyles approximating those to be found in the wealthy north of Italy. Possibly impressed by the images of locked-down Italians singing to one another from their balconies, for example, Modi instructed Indians to do likewise on March 22. Misunderstanding this top-down central government directive, crowds jostled each other in noisy street displays across the country, making a mockery of all prior official pleas to observe strict social distancing. Instead of using the lockdown period to test, trace and limit the spread of the virus, the central government organised further stunts aimed at enthusing its middle class supporters - a coordinated "challenge the darkness" lights-off candlelight vigil directive in April that required substantial preparation to avoid potential damage to electrical grid systems, and a flypast with war planes showering flower petals over hospitals at a time that health workers were desperate for PPE and decent working conditions.

Not only was it one of the world's strictest COVID-19 lockdowns, it was also one of the worst planned. From the standpoint of India's working poor and her destitute masses, it was as if the class war had suddenly turned nuclear. In 1993-1994, in an effort to understand the nature of everyday rural poverty in India, the journalist P. Sainath resolved to spend a 1-year period in the 10 poorest districts in the country, and discovered that the rural poor were forced by their circumstances to be exceptionally mobile. "I mostly visited the districts in the off-agricultural seasons", he writes in the ethnographically textured book that came out of this experience. "The question for me was: What do the poor do in some 200-240 days during which there is no agriculture in their areas? How do they survive? What are their coping mechanisms? What kind of jobs do they find? The answers led me to far more than the ten districts I had set out to cover. In most of these areas, huge sections of the population simply upped and migrated after the harvest. Often, they took their families with them. So I ended up travelling and living with the migrants in districts other than my own. At the end of it, I had covered close to 80,000 km in seven states across the country" (Sainath 1996: xi). Decades later, there is greater awareness of the massive volume of internal migration, not least because of the efforts made by Sainath and the People's Archive of Rural India. Yet the central government made no preparation or provision whatsoever for India's migrant workers when it abruptly imposed the 21-day lockdown.

All passenger trains were suspended by the Railway Ministry two days before the lockdown, and all road transport was halted once it began. Tens of millions of migrants from rural India working in Indian cities - a vast proportion of them daily wage workers in the informal sector-became unemployed overnight, and in many cases were rendered homeless as they lost access to workplace-based accommodation. Thus began their desperate journeys on foot or bicycle to their home villages hundreds or thousands of kilometres away. They also had to contend with the police enforcement of the lockdown and its requirement that everybody stay at home, regardless of whether they had homes or not. Both Indian and international media have recorded the beatings, torture and humiliation India's impoverished masses have had to 
endure at the hands of the police for contravening lockdown regulations (Yadav 2020; AbiHabib and Yasir 2020). Faced with starvation, migrant families continued to walk for days with their few belongings along the national highways, without any form of central government assistance. Efforts by private individuals, NGOs and some state governments to step into the breach could not prevent the many hundreds of non-COVID deaths of migrant workers and their kin due to exhaustion, road accidents, starvation, police brutality and other lockdownrelated causes. Belated central government efforts to provide some relief and organise special trains in the wake of migrant protests were themselves poorly carried out, and resulted in further deaths due to hunger, thirst and exhaustion. We will never know how many people lost their lives on this particular Trail of Tears - one attempt to estimate deaths had listed 684 entries by early July, with many of these entries encompassing several family members (Thejesh et al. 2020). The subcontinent has not witnessed human displacement on this scale since the Partition of India in 1947.

All of this for nothing. Conventional economists are left marvelling at an exceptionally severe lockdown that has produced the worst of all possible worlds - the "double shock" in Kaushik Basu's words, of out-of-control rates of infection and death accompanied by spectacular economic collapse. Thus, Basu writes: "At the time of the announcement, with a fourhour notice, there was a natural expectation that the government had plans of how to handle the sudden stoppage of work and movement of people, and the break in supply chains. But there was no evidence of any of these ancillary actions. I do not have enough information to know what plans there were, but the total absence of any supporting action, to ramp up testing, expand the medical sector and to help the millions of stranded poor workers, was baffling" (Basu 2020).

Inevitably, the lockdown has also been a crackdown. It has targeted India's Muslim minorities, with senior BJP figures vilifying all Muslims and stoking fears of a "Corona-jihad" in the wake of the discovery in March 2020 of a cluster of COVID-19 cases traceable to the headquarters of the Tablighi Jamaat, an Islamic organisation based in New Delhi (Menon 2020; Jain 2020). It has also provided cover for the gutting of the most basic legal protections for Indian labour - some states have passed ordinances legalising the 12-hour working day and doing away with grievance redressal processes. These moves draw on the received wisdom that India's industrialisation has been held back by laws favourable to labour, an assumption flatly contradicted by the careful analysis advanced by the economist Aditya Bhattacharjea (Bhattacharjea 2019). The COVID-19 lockdown/crackdown has enabled the central government to imprison and harass with impunity the university students and public intellectuals who had stood up to them earlier this year to protest the anti-Muslim CAA-NRC-NPR legal apparatus (The Polis Project 2020). The space for hope that had been opened up by that movement recedes further into the distance every day.

\section{References}

Abi-Habib, Maria and Samir Yasir. 2020. India's coronavirus lockdown leaves vast numbers stranded and hungry. The New York Times. 29 March 2020. https://www.nytimes.com/2020/03/29 /world/asia/coronavirus-india-migrants.html?action=click\&module=RelatedLinks\&pgtype=Article. Accessed 19 August 2020.

Basu, Kaushik. 2020. The way in which it was executed, India's lockdown itself became source of virus's spread. The Indian Express, 8 July 2020. https://indianexpress.com/article/opinion/columns/coronavirus-lockdownindia-covid-19-cases-deaths-6494930/. Accessed 19 August 2020. 
Bhattacharjea, Aditya. 2019. Labour market flexibility in Indian industry: a critical survey of the literature. Working Paper No. 296. Centre for Development Economics. Delhi School of Economics.

Jain, Ritika. 2020. How India's government set off a spiral of islamophobia. Article 14. https://www.article-14. com/post/how-india-s-government-set-off-a-spiral-of-islamophobia. Accessed 19 August 2020.

Menon, Nivedita. 2020. The virus, the Muslim and the migrant. Kafila. https://kafila.online/2020/04/22/thevirus-the-muslim-and-the-migrant-part-i-comvid-14/. Accessed 19 August 2020.

Panicker, Prem. 2020. A million mutinies tied together by humanity and hope. The Wire. https://thewire. in/rights/million-mutinies-humanity-caa-revolution. Accessed 19 August 2020.

Petherick, Anna et al. 2020. Variations in government response to COVID 19. Blavatnik Centre for Government Working Paper, University of Oxford.

Sainath, P. 1996. Everybody loves a good drought. New Delhi: Penguin Books.

The Polis Project. 2020. Manufacturing evidence: how the police is framing and arresting constitutional rights defenders in India. https://thepolisproject.com/wp-content/uploads/2020/08/Manufacturing-Evidence-.pdf. Accessed 19 August 2020.

Thejesh, G.N., Kanika Sharma, Aman and Krushna. 2020. Non virus deaths. https://thejeshgn. com/projects/covid19-india/non-virus-deaths/. Accessed 19 August 2020.

Yadav, Jyoti. 2020. Real social distancing: special planes for India's rich, police lathis for working-class poor. The Print. https://theprint.in/opinion/real-social-distancing-special-planes-india-rich-police-lathis-workingclass-poor/389659/. Accessed 19 August 2020.

Publisher's note Springer Nature remains neutral with regard to jurisdictional claims in published maps and institutional affiliations. 